\title{
ADOPTION OF INTEGRATED REPORTING IN EMERGING
ECONOMIES: EVIDENCE FROM BAHRAIN
}

iD Salwa M. A.

Hameed $^{1}$

iD Noora A. R.

Rahman Ahmed ${ }^{2+}$

\author{
'Assistant Professor, Department of Accounting, University of Bahrain, \\ Sakhir, Kingdom of Bahrain. \\ ${ }^{2}$ Graduate Assistant (Master), Department of Accounting, University of \\ Bahrain, Sakhir, Kingdom of Bahrain. \\ Email:naahmed@uob.edu.bh
}

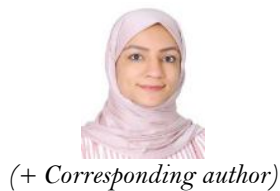

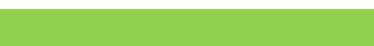

Article History

Received: 11 August 2020 Revised: 27 August 2020 Accepted: 24 September 2020 Published: 19 October 2020

\section{Keywords}

Financial reporting Integrated reporting Voluntary disclosures Emerging economies Bahrain

Content analysis

JEL Classification: M49.

\section{ABSTRACT}

This study investigated the extent to which integrated reporting has been implemented and the factors that determine its adoption in Bahrain. The annual reports of companies listed on the Bahrain Bourse were examined for the period 2017-2019. Then, content analysis was conducted to assess the extent of integrated reporting in 16 listed companies through the integrated reporting index (IRI), which comprises 45 disclosure items divided across 6 categories. The results indicated that the companies sampled had moved toward integrated reporting between 2017 and 2019, despite it not yet being mandatory in Bahrain. The most frequent disclosures concerned principal activities and markets, reporting boundary, accounting standards, and the link between past and current performance. However, no disclosures were provided for social risks and opportunities, as well as stakeholders' involvement in forming and resource allocation for implementing strategy; moreover, corporate reports neglected any forward-looking outlook, while disregarding performance indicators. extended further regression analysis was performed to identify the determinants for adopting integrated reporting, specifically company-specific characteristics. The results revealed that IRI is significantly and positively related to company size.

Contribution/Originality: This study contributes to the current body of literature on integrated reporting in two areas: first, it enriches the corpus by focusing on a developing country, Bahrain, where few studies have been undertaken; second, it provides empirical evidence on the determinants for the extent to which integrated reporting has been adopted.

\section{INTRODUCTION}

A growing trend in corporate financial reporting is comparability and accountability (Rupley, Brown, \& Marshall, 2017). Due to criticism for only reporting information about a company's past performance and little on its future alongside corporate financial scandals, the need for more stringent financial and non-financial information requirements were emphasized (Nakib \& Dey, 2018). Consequently, global pressure led to stand-alone corporate social responsibility (CSR) reporting (Rupley et al., 2017); however, both shareholders and stakeholders in general now demand more holistic information of a company. Integrated reporting has thus emerged: comprising not only financial but also economic, governance, and social aspects of a company, it focuses on multiple stakeholders and connects past performance with the future outlook (Rupley et al., 2017). 
The purpose of integrated reporting is to present stakeholders with a thorough understanding of company strategy, performance, and management of sustainability challenges (International Integrated Reporting Council (IIRC), 2011). Integrated reports, therefore, provide an overall view of a company's business model and its strategies to achieve its goals, including risk management, effective governance, and analysis of and response to the external environment (Eccles \& Krzus, 2010).

In Bahrain, the Commercial Companies Law promulgated by Decree Law No. (21) of 2001 regulates both public and closed joint-stock companies, partnership companies, limited liability companies, holding companies, the transformation and expiration of companies, and the practice and activities of foreign companies in the Kingdom of Bahrain. In particular, Article (195) requires each company to send the original detailed list, approved by the chairman, managing director, and board, of the names and designations of the chairman, members of the board, and company managers to the Ministry of Commerce every year. In addition, the board of directors should prepare, no later than three months following the year end, an annual report covering their company's activities and financial position during the preceding year, including the company's profit and loss account and balance sheet, each of which should be signed by the chairman and another board member. Thus, the board is responsible for implementing (Article, 195), and also Article (196), which requires the board to publish both the profit and loss account and balance sheet as well as a summary of the annual report and the full auditor's report in a local Arabic-language daily newspaper at least 15 days before the annual general meeting.

However, integrated reporting is not yet mandatory in Bahrain. Nevertheless, some companies have progressed from traditional reporting to integrated reporting. This study therefore investigates whether and to what extent Bahraini company reports cover the elements of the integrated reporting framework developed by the IIRC between 2017 and 2019. Furthermore, it examines the impact of certain company-specific characteristics on the extent of integrated reporting.

This paper is organized as follows: Section 2 discusses the development of integrated reporting; Section 3 presents the theoretical basis to integrated reporting; Section 4 reviews previous studies on the subject; Section 5 explains the research methodology; Section 6 discusses the results; and finally, Section 7 offers conclusions based on those findings.

\section{DEVELOPMENT OF INTEGRATED REPORTING}

In recent years, corporate financial reporting has been criticized for providing insufficiency information to assess how the positive and negative impacts a company exerts on the economic, social, and environmental aspects of its local community. Indeed, Yen (2004) stated that the accounting and financial data provided was declining in its ability to provide useful information for evaluating a company's value and management performance.

Over the latter decades of the $20^{\text {th }}$ century, companies changed how they reported their impact on their stakeholders, and by the end of that century, trend-setting companies started to publish CSR reports explaining their impact on the environment and wider society, which an increasing number of companies have since imitated (KPMG, 2010). Many companies publish separate financial and CSR/sustainability reports (South African Institute of Chartered Accountants (SAICA), 2010), but stand-alone sustainability reports fail to connect environmental, social, and governance (ESG) issues to business strategy and financial performance (Krzus, 2011). A new format that incorporated all aspects of a company's performance thus became essential to provide all stakeholders with a more holistic assessment (Ligteringen \& Arbex, 2010).

The solution was integrated reporting, encompassing previously separate reports (e.g., annual, sustainability, CSR) in a single, concise, holistic publication (Rowbottom \& Locke, 2013). The initial motivation was the necessity to present both financial and non-financial information together to enable effective capital allocation: the first integrated report was published by Novozyme, the Danish enzymes company, in 2002. In 2010, The King Code of Governance (King III) in South Africa recommended companies to prepare integrated reports rather than separate 
annual and sustainability reports (SAICA, 2010), which then became a requirement for companies listed on the Johannesburg Stock Exchange (JSE). In the same year, the IIRC was established, launching a discussion paper on the first proposals for the International Integrated Reporting Framework, consisting of eight Content Elements and seven Guiding Principles, in 2011.

\section{THEORETICAL BASIS OF INTEGRATED REPORTING}

There is no specific theory for integrated reporting, but there are several theories whose approaches reinforce the concept (Magnaghi \& Aprile, 2014), notably the stakeholder, legitimacy, and institutional theories.

Legitimacy theory is based on the notion that a social contract exists between society and an organization. As society permits companies to own and use natural resources and hire employees, companies are ultimately accountable to society for how it operates (Deegan, 2004); if a company is considered by society to have breached the social contract, then the company's survival is threatened. Thus, legitimacy is a resource on which companies depend for their existence (Dowling \& Pfeffer, 1975).

Stakeholders theory posits that companies are accountable to not only their owners or shareholders but also those stakeholders with specific interests in those companies (Freeman, 1984). Companies whose primary objective is to generate profits for shareholders are still required to be socially responsible in satisfying the legitimate interests and needs of different stakeholders. This is demonstrated through the voluntary disclosures of the company, which sustain a positive relationship with and gain support from the stakeholders (Magnaghi \& Aprile, 2014). Thus, stakeholder theory considers CSR reporting as a reflection of a company's accountability to its stakeholders-employees, suppliers, regulators, governments, customers, and society at large (Gray, Owen, \& Adams, 1996)—who are best-served by integrated reporting.

According to institutional theory, organizations are influenced by their external environment: financial, political, educational, cultural, and economic institutions pressurize organizations to comply with their directives (Jackson \& Apostolakou, 2010). Companies are thus economic units operating within environments in which institutions impose expectations and affect their behavior (Campbell, 2007; Roe, 1991, 1994), the acceptance of which enables companies to adopt uniform practices in different countries with similar directives (Claessens \& Fan, 2002; Porta, Lopez-De-Silanes, Shleifer, \& Vishny, 1998). This process, termed isomorphism (Dimaggio \& Powell, 1983), is believed to promote the stability and long-term survival of companies by equipping them with greater power and institutional legitimacy.

With regard to integrated reporting, therefore, Jensen and Berg (2012) identified not only a company's ownership structure but also a country's value system, laws protecting investors, and level of corporate responsibility as potential determinants. In fact, it has been observed that more companies publish integrated reports: in countries with strong investment laws; in a sector with dispersed ownership; where they originate from a country that values self-expression; where a high level of national corporate responsibility implies a comprehensive institutional system emphasizing integrated reporting. Campbell (2006) further argues that more companies assume and report social responsibility when operating in an institutional context with a coercive and normative approach: where a robust, well-developed legal system exists to protect not only shareholders' but also stakeholders' interests.

Civil more than common law legal systems are stakeholder-oriented: several studies have found civil law to be more sensitive to stakeholders' interests in a range of countries (Ball, Kothari, \& Robin, 2000; Simnett, Vanstraelen, \& Chua, 2009). As already mentioned, companies granted legal status by the country in which they operate will tend to provide a greater amount of non-financial complementing financial data-integrated reporting-to fulfill that society's expectation of social responsibility (Ball et al., 2000; Kolk \& Perego, 2008; Simnett et al., 2009). On the other hand, common law is shareholder-oriented, due to being the most important stakeholder who can influence managerial decision-making (Prado-Lorenzo, Garcia-Sanchez, \& Blazequez-Zaballos, 2012). However, a 
stronger tradition and development of ownership rights, alongside the consequent protection, results in a greater prevalence of financial reports (Ali \& Hwang, 2000; Ball et al., 2000; Holthausen, 2009; Hung, 2001; Leuz, Nanda, \& Wysocki, 2003) compared with sustainability and integrated reports that summarize diverse information.

Moreover, Meek, Roberts, and Gray (1995) and Fekrat, Inclan, and Petroni (1996) identified significant variation in corporate environmental disclosure by companies in different countries. Specifically, Smith, Adhikari, and Tondkar (2005) found that companies in stakeholder-oriented countries published more and higher-quality corporate environmental and social reports than those in shareholder-oriented countries. Meanwhile, Kolk and Perego (2008) observed that companies in civil law-based countries were more likely to publish sustainability reports, while Frias-Aceituno, Rodriguez-Ariza, and Garcia-Sanchez (2013) discovered from a sample of 750 international companies over the period 2008-2010 that those operating under civil law legal systems, and with high law and order, were more likely to publish a range of integrated reports. Thus, countries preferring civil law favor the influence of different stakeholders on management decision-making.

\section{LITERATURE REVIEW}

The criticism of traditional corporate reporting for its focus on short-term, historic performance has resulted in the concept of integrated reporting to resolve this deficiency (Association of Chartered Certified Accountants (ACCA), 2011). Integrated reporting should disclose details on how the company will create value in the mediumand long-term (Marcon \& Mancin, 2016), on which investors' financial returns depend(IIRC, 2013). Thus, a company should explain its method for achieving its goals, based on the ethical decision-making and practices of management, overseen via governance procedures, and appropriately allocating financial, intellectual, social, and environmental capital (Abeysekera, 2013; ACCA, 2011).

Many case studies have been conducted on the theoretical development of integrated reporting (e.g., Haji \& Hossain, 2016; Higgins, Stubbs, \& Love, 2014; Macias \& Farfan-Lievano, 2017; Solomon \& Maroun, 2012; Toit, Van Zyl, \& Schütte, 2017), as well as empirical studies using content analysis to determine the extent to which integrated reporting has been adopted (e.g., Haji \& Anifowose, 2017; Jamal \& Ghani, 2016; Kilic \& Kuzey, 2018; Lipunga, 2015). From the beginning, Adam and Simnett (2011) argued that the integrated reporting framework needed to be tested in organizations of different sizes evaluate its flexibility and therefore applicability, and size was found to be a prominent factor influencing voluntary disclosure (Ghasempour \& Yusof, 2014; Ibrahim, 2014; Uyar, Kilic, \& Bayyurt, 2013). Frias-Aceituno et al. (2013) further concluded that the decision to publish integrated reports were based mainly by not only the company's size but also acceptance by and diversity of management. Focusing on listed real estate companies in Malaysia, Jamal and Ghani (2016) confirmed that company size was significantly and positively associated with the extent that integrated reporting practices were adopted, which were weak in this sector. Likewise, Kilic and Kuzey (2018) found a positive correlation with company size, as well as gender diversity.

Evaluating the context in addition to adoption of integrated reporting, Churet and Eccles (2014) reported the growing number of companies publishing integrated reports from 2010 to 2012. They also found a strong relationship between integrated reporting and quality of ESG management, which indicates the overall quality of management as well. Shabeeb and Ahmed (2016) aimed to specifically explain the extent and determinants of integrated reporting among 106 listed Saudi banks. They discovered integrated reporting was still rare and remained much the same throughout 2013 and 2014 period, possibly due to the significant influence of company size and type of auditor.

With regard to sustainability reporting, Gurvitsh and Sidorova (2012) conducted a survey of inclusion in the annual reports of listed Estonian companies between 2007 and 2010. Results showed a continuous increase in accounting disclosures of social and environmental activities, not in stand-alone CSR reports but in integrated sustainability and annual reports. Ayoola and Olasanmi (2013) also examined the adoption of integrated reporting 
in the Nigerian oil and gas sector. In this case, ESG reporting was ad hoc, short-term, and unrelated to core activities, revealing that sustainability was not integrated into their business model and strategies; moreover, although duplicated across various medium, ESG was presented in a haphazard and midleading manner.

From a wider perspective, Peršić and Halmi (2017) attempted to explore the specifics of non-financial information and integrated reporting in the Croatian hospitality sector and uncovered very few companies disclosing non-financial information within their annual reports, or of a satisfactory quality to satisfy national regulations. Meanwhile, the progress from stand-alone CSR to integrated reporting was also examined by Rupley et al. (2017) through an analysis of the reports from eight front-running US companies, finding that, overall, current integrated reports do not provide the information most highly rated by investors.

In South Africa, Solomon and Maroun (2012) investigated 10 listed companies considered to exert a high social and environmental impact. They found that despite the significant increase in integrated reporting between 2009 and 2011, following the King III report, information was repeated and rephrased while social, environmental, and ethical aspects were excluded. This weakness may be due to companies either attempting to best present the small amount of information available or not knowing how to approach integrated reporting. An improvement in this aspect was indicated in a similar study by Toit et al. (2017) that compared the change in integrated reporting during 2012-2014 and 2009-2011 of four South African companies exerting a high social and environmental impact. However, the overall value of the more recent integrated reports declined as some information provided in 2011 was excluded and not followed up in 2014.

The reasons for and benefits of adopting integrated reporting were investigated through a case study in Italy by Vitolla and Raimo (2018), which showed that pressure from external stakeholders was not enough to implement integrated reporting - support from top management played an important role. Moreover, they demonstrated that adopting integrated reporting had a positive impact on the company, internally and externally. Elsewhere, Nakib and Dey (2018) examined the extent to which listed Bangladeshi companies had adopted integrated reporting between 2014 and 2016. The finding that $22 \%$ of the companies sampled had published integrated reports in 2016 compared with none in 2014 indicated that companies have started either integrated reporting or integrating nonfinancial information into their annual reports, despite the absence of any mandatory requirement-the integrated reporting index (IRI) for all companies sampled rose from 0.6148 from 0.4511 over the three-year period. The same type of investigation was conducted in Bahrain by Alqallaf and Alareeni (2018), but in the banking sector. An examination of integrated reports from 12 listed banks between 2014 and 2015 revealed an average level of adoption and that most of the disclosures concerned intellectual capital.

The aforementioned studies have led to the quality of integrated reporting becoming the focus of recent research. In this context, quality is defined not as strict compliance with a framework but as approaching about the task with a long-term, broad, more operational perspective that challenges companies' assumptions (PricewaterhouseCoopers, 2014). Quality also refers to how effectively integrated reports present the strategic elements that demonstrate performance and creation of value. The main criticism in the literature on the quality of integrated reporting is the failure to link business model, strategy, performance, and future outlook (Pistoni, Songini, \& Bavagnoli, 2018): Eccles and Krzus (2014) stated that "It is not solely the absolute number of companies practicing integrated reporting, but the quality of adoption that matters .... Although companies may achieve a truly integrated report by other means, the effectiveness with which they apply these frameworks and standards will determine how useful these reports are to investors.” (p. 191).

Consequently, Pistoni et al. (2018) analyzed 116 integrated reports from 58 companies for 2013 and 2014. Although some improvement was observed in form and content, they discovered that overall quality remained limited, particularly in terms of content: little was disclosed on capital, business model, strategic priorities, and the process of creating value creation. Matemane and Wentzel (2019) similarly examined quality through the relationship between integrated reporting and financial reporting by listed South African banks from 2005 to 2009. 
They showed that these banks had not yet adopted a long-term view of creating value, focusing instead on earnings per share in the short term.

\section{RESEARCH METHODOLOGY}

\subsection{Sampling and Data Collection}

This study focuses on companies listed on the Bahrain Bourse, from which commercial banks, and investment and insurance companies were excluded due to their unique financial reporting practices. Hence, the final sample comprised 16 companies from the service, industrial, hotel, and tourism sectors, as presented in Table 1.

Table-1. Sample of companies.

\begin{tabular}{l|l}
\hline 1 & APM Terminals Bahrain B.S.C. \\
\hline 2 & Bahrain Car Parks Company B.S.C. \\
\hline 3 & Bahrain Cinema Company B.S.C. \\
\hline 4 & Bahrain Duty Free Shop Complex B.S.C. \\
\hline 5 & Bahrain Ship Repairing \& Engineering Company B.S.C. \\
\hline 6 & Bahrain Telecommunication Company \\
\hline 7 & BMMI B.S.C. \\
\hline 8 & Nass Corporation B.S.C. \\
\hline 9 & Seef Properties \\
\hline 10 & Trafco Group B.S.C. \\
\hline 11 & Zain Bahrain B.S.C. \\
\hline 13 & Bahrain Family Leisure \\
\hline 14 & Gulf Hotels Group B.S.C. \\
\hline 15 & National Hotels Company \\
\hline 16 & Bahminium Bahrain B.S.C. \\
\hline Source: Bahrain Bourse.
\end{tabular}

The annual reports for the period from 2017 to 2019 were collected from the official websites of each of these companies. Where reports were missing, those companies were also excluded, resulting in 45 annual reports for analysis.

\subsection{Integrated Reporting Index (IRI)}

To determine the extent to which integrated reporting had been adopted by the sampled companies, content analysis, widely recognized and used for social and environmental research, was conducted (Brennan \& Solomon, 2008; Gao, Heravi, \& Xiao, 2005; Nakib \& Dey, 2018). A common approach was adopted, in which the appearance of specific items were analyzed using a non-weighted disclosure index (Louie, Ahmed, \& Ji, 2019; Oliveira, Rodrigues, \& Craig, 2010; Setia, Abhayawansa, Joshi, \& Huynh, 2015): if the company disclosed a specific item at least once, a score of 1 was assigned, otherwise 0 .

The disclosure index employed in this study, hereafter referred to as the integrated reporting index (IRI), focuses on the content elements of the integrated reporting framework developed by the IIRC (2013): a total of 45 items are included within six categories: organizational overview and outlook; governance; business model; risk and opportunities; strategy and resource allocation; and performance-details of all categories and their associated items are provided in the Appendix. To evaluate the extent to which the sampled companies engaged in integrated reporting, each company's IRI was calculated using the following formula:

$$
I R I=\frac{\sum_{i=1}^{t} I R_{i}}{t}
$$

Where:

IRI = Integrated reporting index. 
$I R_{\mathfrak{i}} \quad=0$ if item not disclosed; 1 if item disclosed.

$t \quad=$ Maximum number of items company could disclose (i.e., 45).

To identify the factors that determine the extent to which integrated reporting was adopted, company-specific characteristics were examined. Based on the findings of earlier studies, four factors were selected-company size, leverage, profitability, and size of the board of directors - the following random effects regression model estimated:

$$
I R I=\beta_{0}+\beta_{1} \text { Size }+\beta_{2} L E V+\beta_{3} R O A+\beta_{4} B O D \_S I Z E+\varepsilon
$$

Where:
Size
LEV
$=$ Company size, measured as the natural logarithm of total assets.
$R O A$
$=$ Leverage, measured as the ratio of total debt to equity.
BOD_SIZE
$=$ Profitability, measured as the percentage of net income to total assets.
$=$ Total absolute number of board members.

\section{RESULTS AND DISCUSSION}

Table 2 presents a summary of the descriptive statistics from 2017 to 2019 for the overall IRI of all the companies sampled.

Table-2. Summary of descriptive statistics for IRI of sampled companies.

\begin{tabular}{l|c|c|c|c}
\hline Year & $\mathbf{2 0 1 7}$ & $\mathbf{2 0 1 8}$ & $\mathbf{2 0 1 9}$ & 3-Year Period \\
\hline No. of observations & 14 & 16 & 15 & 45 \\
\hline Mean & 0.373 & 0.393 & 0.430 & 0.399 \\
\hline Median & 0.333 & 0.367 & 0.400 & 0.378 \\
\hline Standard deviation & 0.110 & 0.108 & 0.116 & 0.111 \\
\hline Minimum & 0.244 & 0.244 & 0.289 & 0.244 \\
\hline Maximum & 0.667 & 0.689 & 0.689 & 0.689 \\
\hline ANOVA test & \multicolumn{5}{|c}{ F-value $=0.97 ;$ P value $=0.387$} \\
\hline
\end{tabular}

As shown, the mean IRI over the three-year period is $40 \%$ (0.399), indicating that $40 \%$ of the content items proposed by the IIRC's framework were disclosed. However, there is a considerable variance, ranging from 0.244 minimum to 0.689 maximum, reflecting considerable wide variation in integrated reporting across the sample. Furthermore, although the mean IRI increased slightly between 2017 (37\%) and 2019 (43\%), the ANOVA test result $(\mathrm{F}=0.97 ; \mathrm{P}=0.387$ ) reveals the change to be insignificant.

Despite this evident progress toward integrated reporting, the need for further improvement is obvious. This finding accords with not only that of Alqallaf and Alareeni (2018), who reported that Bahraini banks had implemented only an average level of integrated reporting, but also of Nakib and Dey (2018), who reported that the IRI for Bangladeshi companies had increased even in the absence of any mandatory requirement.

In relation to the IRI, Table 3 presents the level of disclosure across the sample in terms of the number and percentage of companies providing information for each item within the six categories of the integrated reporting framework. For organizational overview and outlook, Panel (A) shows that all the companies included disclosures on principal activities and markets, reporting boundary, and reporting frameworks all of which were mandatory under the Commercial Companies Law. In addition, over $85 \%$ of companies stated their corporate ethics and values; however, only $21 \%$ included sustainability within their corporate mission/vision in 2017 , which increased to $31 \%$ and 33\% in 2018 and 2019, respectively. In Estonia, Gurvitsh and Sidorova (2012) also discovered a determination to integrate sustainability reporting into their annual reports.

Panel (B) presents the results on governance disclosures, revealing that most companies described their leadership structures, as well as an increasing number detailing the monitoring procedures for their strategic directions. An upward trend is also observed in companies disclosing engagement with stakeholders to create value (from $36 \%$ in 2017 to $47 \%$ in 2019), which is consistent with the results of Shabeeb and Ahmed (2016) that showed 
disclosures for all governance items had been increasing over time. Nevertheless, it is notable that governance practices exceeding legal requirements was the least disclosed item in this category (14\% in 2017 and $27 \%$ by 2019 ).

The results for disclosures on the business model are presented in Panel (C), among which all companies provided information about improvements to their business processes in 2019. An upward trend is also evident in disclosures on key stakeholders over the three-year period (64\% in 2017 and $73 \%$ in 2019), as well as for product and service innovations (from $57 \%$ in 2017 to $67 \&$ in 2019). In contrast, the least disclosed items were by-products and waste and relationships with suppliers, by $20 \%$ and $7 \%$ of companies in 2019, respectively. The increasing tendency toward overall disclosure under business model was also reported by Shabeeb and Ahmed (2016).

Panel (D), risk and opportunities, indicates that the majority of the companies (87\% in 2019) had identified their external economic risks, whereas only $60 \%$ identified internal risks and external economic opportunities in the same year. Simultaneously, legal and political riskswere disclosed by just $20 \%$ of companies, revealing the need major improvements in this area. Similarly, companies provided no information on social risks or opportunities, or on the potential for risks and opportunities to come to fruition. It can be inferred that in the absence of mandatory requirements under Bahrain's Commercial Companies Law, companies lack the initiative to disclose such information.

Under strategy and resource allocation, in Panel (E), most disclosures were related to strategic objectives and the social and environmental aspects of strategy, both reaching 87\% in 2019). In addition, a slight rise can be seen in companies disclosing both the means for assessing the implementation of their strategy, from $50 \%$ in 2017 to $53 \%$ in 2019, as well as the changes to their business models for implementing strategies, from $43 \%$ in 2017 to $47 \%$ in 2019. This corresponds with the results reported by Shabeeb and Ahmed (2016). However, companies are disclosing how they respond to external risks and opportunities less and less, from $43 \%$ in 2017 to $40 \%$ in 2019 , possibly due to the threat of losing competitive advantage in the market.

The results under performance shown in Panel $(\mathrm{F})$ reveal that all the companies disclosed the connection between their past and current performance, as did Nakib and Dey (2018). In contrast, very few disclosed the link between current performance and future outlook over the three-year period (less than 15\%), which corroborates the criticism that financial reporting lacks forward-looking information. Furthermore, the results show that companies provided no details of the quantitative indicators used for targets or risks and opportunities, or the key performance indicators (KPIs) linking financial and non-financial measures. 
Table-3. Disclosure levels in relation to the integrated reporting index.

\begin{tabular}{|c|c|c|c|c|c|c|c|}
\hline \multirow{2}{*}{ Category } & \multirow{2}{*}{ Disclosure items } & \multicolumn{2}{|c|}{2017} & \multicolumn{2}{|c|}{2018} & \multicolumn{2}{|c|}{2019} \\
\hline & & Frequency & $(\%)$ & Frequency & $(\%)$ & Frequency & $(\%)$ \\
\hline \multirow{6}{*}{ 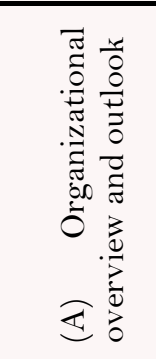 } & 1. Integration of sustainability within corporate mission/vision & 3 & 21.43 & 5 & 31.25 & 5 & 33.33 \\
\hline & 2. Stating corporate ethics and values & 12 & 85.71 & 14 & 87.50 & 13 & 86.67 \\
\hline & 3. Showing the organization's principal activities and markets & 14 & 100 & 16 & 100 & 15 & 100 \\
\hline & 4. Providing the implications for future financial performance & 8 & 57.14 & 11 & 68.75 & 11 & 73.33 \\
\hline & $\begin{array}{l}\text { 5. Describing the reporting boundary (i.e., subsidiaries and } \\
\text { associates, as well as related parties, included) }\end{array}$ & 14 & 100 & 16 & 100 & 15 & 100 \\
\hline & $\begin{array}{l}\text { 6. Describing the frameworks used to quantify material aspects } \\
\text { (e.g., accounting standards, corporate social responsibility } \\
\text { (CSR) framework) }\end{array}$ & 14 & 100 & 16 & 100 & 15 & 100 \\
\hline \multirow{6}{*}{ 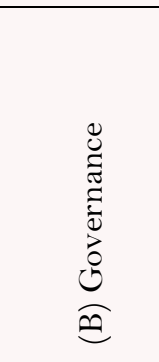 } & 7. Clear leadership structure & 13 & 92.86 & 15 & 93.75 & 14 & 93.33 \\
\hline & $\begin{array}{l}\text { 8. Processes/actions taken to influence and monitor the } \\
\text { strategic direction of the organization }\end{array}$ & 8 & 57.14 & 11 & 68.75 & 14 & 93.33 \\
\hline & $\begin{array}{l}\text { 9. How the organization's leadership engage with key } \\
\text { stakeholders to create value }\end{array}$ & 5 & 35.71 & 6 & 37.50 & 7 & 46.67 \\
\hline & 10. Governance practices that exceed legal requirements & 2 & 14.29 & 3 & 18.75 & 4 & 26.67 \\
\hline & $\begin{array}{l}\text { 11. How the organization's leadership promote and enable } \\
\text { innovation }\end{array}$ & 3 & 21.43 & 7 & 43.75 & 9 & 60 \\
\hline & 12. Linking remuneration and incentives with value creation & 5 & 35.71 & 6 & 37.50 & 6 & 40 \\
\hline \multirow{4}{*}{ 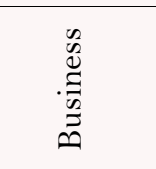 } & 13. Identifying material matters affecting value creation & 5 & 35.71 & 7 & 43.75 & 7 & 46.67 \\
\hline & 14. Identification of key stakeholders & 9 & 64.29 & 11 & 68.75 & 11 & 73.33 \\
\hline & 15. Product and service innovations & 8 & 57.14 & 9 & 56.25 & 10 & 66.67 \\
\hline & 16. Improvement of processes & 13 & 92.86 & 15 & 93.75 & 15 & 100 \\
\hline \multirow{3}{*}{$\underbrace{\frac{\Xi}{0}}$} & 17. Training employees on sustainability aspects & 2 & 14.29 & 3 & 18.75 & 4 & 26.67 \\
\hline & 18. Managing relationships with suppliers & 1 & 7.14 & 1 & 6.25 & 1 & 6.67 \\
\hline & 19. Identification of by-products and waste & 1 & 7.14 & 1 & 6.25 & 3 & 20 \\
\hline \multirow{11}{*}{ 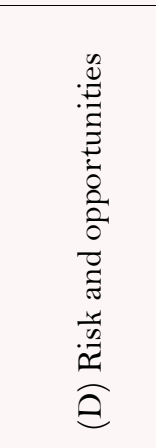 } & 20. Identifying material internal risks & 9 & 64.29 & 10 & 62.50 & 9 & 60 \\
\hline & 21. Identifying material internal opportunities & 5 & 35.71 & 5 & 31.25 & 5 & 33.33 \\
\hline & 22. Identifying material external economic risks & 12 & 85.71 & 14 & 87.50 & 13 & 86.67 \\
\hline & 23. Identifying material external economic opportunities & 9 & 64.29 & 10 & 62.50 & 9 & 60 \\
\hline & 24. Identifying material external environmental risks & 1 & 7.14 & 1 & 6.25 & 2 & 13.33 \\
\hline & 25. Identifying material external environmental opportunities & 1 & 7.14 & 1 & 6.25 & 1 & 6.67 \\
\hline & 26. Identifying material external social risks & 0 & 0 & $\mathrm{O}$ & 0 & 0 & $\mathrm{O}$ \\
\hline & 27. Identifying material external social opportunities & $\mathrm{O}$ & $\mathrm{O}$ & $\mathrm{O}$ & $\mathrm{O}$ & O & $\mathrm{O}$ \\
\hline & 28. Identifying material external legal risks & 3 & 21.43 & 4 & 25 & 3 & 20 \\
\hline & 29. Identifying material external political risks & 2 & 14.29 & 3 & 18.75 & 3 & 20 \\
\hline & 30. Assessment of the potential risks coming to fruition & 0 & 0 & 0 & 0 & 0 & 0 \\
\hline
\end{tabular}


Asian Economic and Financial Review, 2020, 10(10): 1115-1130

\begin{tabular}{|c|c|c|c|c|c|c|c|}
\hline & $\begin{array}{l}\text { 31. Assessment of the potential opportunities coming to } \\
\text { fruition }\end{array}$ & 0 & 0 & 0 & O & 0 & $\mathrm{O}$ \\
\hline \multirow{3}{*}{$\begin{array}{l}\circlearrowright \\
\Xi \\
0 \\
0 \\
0 \\
0\end{array}$} & $\begin{array}{l}\text { 32. Identifying short-, medium-, and long-term strategic } \\
\text { objectives }\end{array}$ & 9 & 64.29 & 10 & 62.50 & 13 & 86.67 \\
\hline & 33. Resource allocation for implementing the strategy & $\mathrm{O}$ & $\mathrm{O}$ & 1 & 6.25 & 1 & 6.67 \\
\hline & $\begin{array}{l}\text { 34. Identifying the means to assess the implementation of the } \\
\text { strategy }\end{array}$ & 7 & 50 & 8 & 50 & 8 & 53.33 \\
\hline 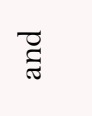 & $\begin{array}{l}\text { 35. How stakeholders' insights form part of the organization's } \\
\text { strategy }\end{array}$ & $\mathrm{O}$ & $\mathrm{O}$ & 0 & 0 & 0 & 0 \\
\hline \multirow{3}{*}{ 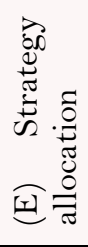 } & $\begin{array}{l}\text { 36. Describing the social and environmental aspects included in } \\
\text { the organization's strategy }\end{array}$ & 8 & 57.14 & 13 & 81.25 & 13 & 86.67 \\
\hline & $\begin{array}{l}\text { 37. Identifying the changes required to the business model for } \\
\text { implementation of the strategy }\end{array}$ & 6 & 42.86 & 5 & 31.25 & 7 & 46.67 \\
\hline & $\begin{array}{l}\text { 38. How the strategies respond to external risks and } \\
\text { opportunities }\end{array}$ & 6 & 42.86 & 6 & 37.50 & 6 & 40 \\
\hline \multirow{7}{*}{ 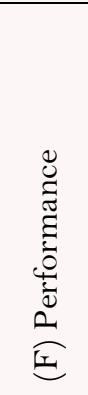 } & 39. Quantitative indicators for the organization's targets & $\mathrm{O}$ & $\mathrm{O}$ & 0 & $\mathrm{O}$ & $\mathrm{O}$ & 0 \\
\hline & 40. Quantitative indicators for risks and opportunities & $\mathrm{O}$ & O & $\mathrm{O}$ & O & $\mathrm{O}$ & $\mathrm{O}$ \\
\hline & $\begin{array}{l}\text { 41. Explaining the organization's capacity to respond to the } \\
\text { stakeholders' needs }\end{array}$ & 1 & 7.14 & 1 & 6.25 & 1 & 6.67 \\
\hline & 42. Showing the link between past and current performance & 14 & 100 & 16 & 100 & 15 & 100 \\
\hline & $\begin{array}{l}\text { 43. Showing the link between current performance and future } \\
\text { outlook }\end{array}$ & 2 & 14.29 & 2 & 12.50 & 2 & 13.33 \\
\hline & 44. KPIs linking financial and non-financial measures & $\mathrm{O}$ & $\mathrm{O}$ & 0 & O & $\mathrm{O}$ & $\mathrm{O}$ \\
\hline & $\begin{array}{l}\text { 45. Identifying constraints on performance due to regulatory } \\
\text { compliance }\end{array}$ & 0 & 0 & 0 & 0 & 0 & 0 \\
\hline
\end{tabular}


To identify the determinants for the extent to which integrated reporting was adopted, a number of companyspecific characteristics were examined: size (total assets), profitability (return on assets; ROA), leverage, and size of the board of directors. Table 4 presents the correlation between these variables: IRI is significantly and positively correlated with company size and leverage, while company size is significantly and positively correlated with leverage and size of board. In addition, this correlation matrix confirms that no multicollinearity exists.

Table-4. Pearson correlation coefficients.

\begin{tabular}{c|c|c|c|c|c}
\hline Variables & IRI & Size & ROA & LEV & BOD_SIZE \\
\hline IRI & 1 & & & & \\
\hline Size & 0.70 & 1 & & & \\
\hline ROA & 0.03 & 0.02 & 1 & & \\
\hline LEV & 0.38 & 0.51 & -0.10 & 1 & \\
\hline BOD_SIZE & 0.26 & 0.45 & -0.07 & 0.10 & 1 \\
\hline
\end{tabular}

The Wald chi-square test also showed the variables to be significant to the model, as can be seen in Table 5, which presents the results from the regression analysis. The positive and significant relationship between IRI and the company's size suggests that larger companies are more likely to engage in integrated reporting, which was also contended in earlier studies(e.g., Frias-Aceituno et al., 2013; Jamal \& Ghani, 2016; Kilic \& Kuzey, 2018; Shabeeb \& Ahmed, 2016). This finding also supports the theory that as larger companies are subject to greater public scrutiny, they are under greater pressure to disclose more information (Hanafi, 2006; Marston \& Polei, 2004). The other three variables, however, exhibited no significant impact on the extent of integrated reporting, as was discovered by previous studies (e.g., Kelton \& Yang, 2008; Kolsi, 2017; Madi, Ishak, \& Manaf, 2014).

Table-5. Regression analysis results

\begin{tabular}{|c|c|c|c|c|}
\hline Independent variables & Coefficient & Std. error & z-score & P Value \\
\hline Constant & -0.715 & 0.322 & -2.22 & 0.027 \\
\hline Size & 0.064 & 0.019 & 3.37 & 0.001 \\
\hline $\mathrm{ROA}$ & -0.052 & 0.075 & -0.68 & 0.494 \\
\hline $\mathrm{LEV}$ & 0.005 & 0.039 & 0.13 & 0.897 \\
\hline BOD_SIZE & -0.008 & 0.010 & -0.80 & 0.426 \\
\hline Adjusted $R^{2}$ & \multicolumn{4}{|c|}{$55.38 \%$} \\
\hline Wald chi-square test & \multicolumn{4}{|c|}{$42.69^{* * * *}$} \\
\hline Observations & \multicolumn{4}{|c|}{46} \\
\hline
\end{tabular}

\section{CONCLUSION}

This study investigated whether, and to what extent, Bahraini companies engaged in integrated reporting from 2017 to 2019. This was assessed by conducting a content analysis derive the IRI. Although integrated reporting is not yet mandatory, the findings revealed that a sample of companies had moved toward integrated reporting over the three-year period. The results further showed that the most frequent disclosures concerned companies' principal activities and markets, reporting boundary, accounting standards, and the link between past and current performance. Nevertheless, it was also evident that there was a failure to disclose information on social risks and opportunities, as well as stakeholders' involvement in forming and resource allocation for implementing strategy. In addition, corporate reports focused on past and current performance while neglecting any forward-looking outlook; moreover, no details were provided on performance indicators. A subsequent examination of company-specific characteristics suggested that the size of companies exerted a positive effect on integrated reporting, indicating that the larger a company, the more likely it would engage in integrated reporting.

These findings raise important implications for regulatory bodies, policy-makers, and standard-setters, as they highlight not only deficiencies in existing reporting practices but also areas for improvement that could promote the adoption of integrated reporting in Bahrain. However, the study suffers several limitations, but these may be 
resolved in future research. First, it focuses on a single country, preventing any generalization from the findings, whereas studies encompassing multiple countries within either the Gulf Cooperation Council (GCC) or the Middle East and North Africa (MENA) region will allow cross-country analysis in future. Second, the use of content analysis carries the risk of presenting an incomplete picture, due to unavoidable subjectivity (Hammond \& Miles, 2004); hence, questionnaires and interviews with stakeholder groups could provide a better insight into the adoption of integrated reporting in the future.

Funding: This study received no specific financial support.

Competing Interests: The authors declare that they have no competing interests.

Acknowledgement: Both authors contributed equally to the conception and design of the study.

\section{REFERENCES}

Abeysekera, I. (2013). A template for integrated reporting. Journal of Intellectual Capital, 14(2), 227-245.

Adam, S., \& Simnett, R. (2011). Integrated reporting: An opportunity for Australia's non-for-profit sector. Australian Accounting Review, 21(3), 291-301.

Ali, A., \& Hwang, L.-S. (2000). Country-specific factors related to financial reporting and the value relevance of accounting data. Journal of Accounting Research, 38(1), 1-21.Available at: https://doi.org/10.2307/2672920.

Alqallaf, H., \& Alareeni, B. (2018). Evolving of selected integrated reporting of capitals among listed Bahraini banks. Journal of Accounting and Applied Business Research, 1(1), 1-21.

Association of Chartered Certified Accountants. (2011). Adoption of integrated reporting by the ASX 50-A joint report from ACCA and the net balance foundation (pp. 3-30). London, United Kingdom: ACCA.

Ayoola, T., \& Olasanmi, O. (2013). Business case for integrated reporting in the Nigerian oil and gas sector. Issues in Social and Environmental Accounting, 7(1), 30-54.Available at: https://doi.org/10.22164/isea.v7i1.74.

Ball, R., Kothari, S., \& Robin, A. (2000). The effect of international institutional factors on properties of accounting earnings. Journal of Sccounting and Economics, 29(1), 1-51.Available at: https://doi.org/10.1016/s0165-4101(00)00012-4.

Brennan, N., \& Solomon, J. (2008). Corporate governance, accountability and mechanisms of accountability: An overview. Accounting, Auditing $\mathcal{E}^{2}$ Accountability Journal, 21(7), https://doi.org/10.1108/09513570810907401.

Campbell, J. L. (2006). Institutional analysis and the paradox of corporate social responsibility. American Behavioral Scientist, 49(7), 925-938.Available at: https://doi.org/10.1177/0002764205285172.

Campbell, J. L. (2007). Why would corporations behave in socially responsible ways? An institutional theory of corporate social responsibility. Academy of Management Review, 32(3), 946-967.Available https://doi.org/10.5465/amr.2007.25275684.

Churet, C., \& Eccles, R. G. (2014). Integrated reporting, quality of management, and financial performance. Journal of Applied Corporate Finance, 26(1), 56-64.

Claessens, S., \& Fan, J. P. (2002). Corporate governance in Asia: A survey. International Review offinance, 3(2), 71-103.

Deegan, C. (2004). Fundamental accounting theory. Australia: McGraw-Hill.

Dimaggio, P., \& Powell, W. (1983). The iron cage revisited. Institutional isomorphism and collective rationality in organizational fields. American Sociological Review, 48(2), 147-160.Available at: https://doi.org/10.2307/2095101.

Dowling, J., \& Pfeffer, J. (1975). Organizational legitimacy: Social values and organizational behavior. Pacific Sociological Reviere, 18(1), 122-136.Available at: https://doi.org/10.2307/1388226.

Eccles, R., \& Krzus, M. (2010). One report: Integrated reporting for a sustainable strategy. New Jersey: John Wiley \& Sons.

Eccles, R., \& Krzus, M. (2014). The integrated reporting movement: Meaning, momentum, motives and materiality. New Jersey: John Whiley \& Sons. 
Fekrat, M. A., Inclan, C., \& Petroni, D. (1996). Corporate environmental disclosures: Competitive disclosure hypothesis using 1991 annual report data. The International Journal of Accounting, 31(2), 175-195.Available at: https://doi.org/10.1016/s0020-7063(96)90003-5.

Freeman, R. (1984). Strategic management: A stakeholders' approach. Boston: Pitman Publishing Inc.

Frias-Aceituno, J. V., Rodriguez-Ariza, L., \& Garcia-Sanchez, I. M. (2013). The role of the board in the dissemination of integrated corporate social reporting. Corporate Social Responsibility and Environmental Management, 20(4), 219233.Available at: https://doi.org/10.1002/csr.1294.

Gao, S., Heravi, S., \& Xiao, J. (2005). Determinants of corporate social and environmental reporting in Hong Kong: A research note. Accounting Forum, 29(2), 233-242.Available at: https://doi.org/10.1016/j.accfor.2005.01.002.

Ghasempour, A., \& Yusof, M. A. B. M. (2014). The effect of fundamental determinants on voluntary disclosure of financial and nonfinancial information: The case of internet reporting on the Tehran stock exchange. The International Journal of Digital Accounting Research, 14(4), 37-56.

Gray, R., Owen, D., \& Adams, C. (1996). Accounting and accountability: Change and challenges in corporate social and environmental reporting. London: Prentice Hall.

Gurvitsh, N., \& Sidorova, I. (2012). Survey of sustainability reporting integrated into annual reports of Estonian companies for the years 2007-2010: based on companies listed on Tallinn stock exchange as of October 2011. Procedia Economics and Finance, 2, 26-34.Available at: https://doi.org/10.1016/s22 12-5671(12)00061-5.

Haji, A., \& Anifowose, M. (2017). Initial trends in corporate disclosures following the introduction of integrated reporting practice in South Africa. Journal of Intellectual Capital, 18(2), 375-399.

Haji, A., \& Hossain, D. (2016). Exploring the implications of integrated reporting on organizational reporting practice: Evidence from highly regarded integrated reporters. Qualitative Research in Accounting and Management, 13(4), 415-444.

Hammond, K., \& Miles, S. (2004). Assessing quality assessment of corporate social reporting: UK perspectives. Accounting Forum, $28(1), 61-79$.

Hanafi, R. (2006). An exploration of corporate social and environmental disclosure in Egypt and the UK: A comparative study. Unpublished PhD Thesis, University of Glasgow, Glasgow, UK.

Higgins, C., Stubbs, W., \& Love, T. (2014). Walking the talk (s): Organisational narratives of integrated reporting. Accounting, Auditing \& Accountability Journal, 27(7), 1090-1 1 19.Available at: https://doi.org/10.1 108/aaaj-04-2013-1303.

Holthausen, R. W. (2009). Accounting standards, financial reporting outcomes, and enforcement. Journal of Accounting Research, $47(2), 447-458$.

Hung, M. (2001). Accounting standards and value relevance of financial statements: An international analysis. Journal of Accounting and Economics, 30(3), 401-420.

Ibrahim, K. (2014). Firm characteristics and voluntary segment disclosure among the largest firms in Nigeria. International Journal of Trade Economics and Finance, 5(4), 327-332.Available at: https://doi.org/10.7763/ijtef.2014.v5.392.

International Integrated Reporting Council. (2011). Towards integrated reporting: Communicating value in the 21 st century. IIRC. Retrieved from https://integratedreporting.org/wp-content/uploads/2011/09/IR-Discussion-Paper2011_spreads.pdf.

International Integrated Reporting Council. (2013). International $<\mathrm{IR}>$ framework. IIRC. Retrieved from https://integratedreporting.org/wp-content/uploads/2015/03/13-12-08-THE-INTERNATIONAL-IRFRAMEWORK-2-1.pdf.

Jackson, G., \& Apostolakou, A. (2010). Corporate social responsibility in Western Europe: An institutional mirror or substitute? Journal of Business Ethics, 94(3), 371-394.Available at: https://doi.org/10.1007/s 1055 1-009-0269-8.

Jamal, J., \& Ghani, E. K. (2016). Integrated reporting practices among real property listed companies in Malaysia. Management $\mathcal{E}^{\circ}$ Accounting Review, 15(1), 251-274. 
Jensen, J. C., \& Berg, N. (2012). Determinants of traditional sustainability reporting versus integrated reporting. An institutionalist approach. Business Strategy and the Environment, 21(5), 299-316.Available at: https://doi.org/10.1002/bse.740.

Kelton, A. S., \& Yang, Y.-W. (2008). The impact of corporate governance on Internet financial reporting. Journal of Accounting and Public Policy, 27(1), 62-87.

Kilic, M., \& Kuzey, C. (2018). Determinants of forward-looking disclosures in integrated reporting. Managerial Auditing Journal, $33(10), 115-144$.

Kolk, A., \& Perego, P. (2008). Determinants of the adoption of sustainability assurance statements: An international investigation. Business Strategy and Environment, 19(3), 182-198.

Kolsi, M. (2017). The determinants of corporate voluntary disclosure policy: Evidence from the Abu Dhabi securities exchange (ADX). Journal of Accounting in Emerging Economies, 7(2), 249-365.Available at: https://doi.org/10.1 108/jaee-12-20150089.

KPMG. (2010). Integrated reporting: Closing the loop of strategy (pp. 1-16). Amsterdan, Netherlands: KPMG

Krzus, M. (2011). Integrated reporting: If not now, when? Blickpunkt: Integrated Reporting, 6(6), 271-276.

Leuz, C., Nanda, D., \& Wysocki, P. D. (2003). Earnings management and investor protection: An international comparison. Journal of Financial Economics, 69(3), 505-527.Available at: https://doi.org/10.1016/s0304-405x(03)00121-1.

Ligteringen, E., \& Arbex, N. (2010). Will integrated reporting make sustainability reporting obsolete? In the landscape of integrated reporting: Reflections and next steps. Cambridge: Harvard Business School.

Lipunga, A. M. (2015). Integrated reporting in developing countries: Evidence from Malawi. Journal of Management Research, 7(3), 130-156.Available at: https://doi.org/10.5296/jmr.v7i3.7195.

Louie, J., Ahmed, K., \& Ji., X. (2019). Voluntary disclosures practices of family firms in Australia. Accounting Research Journal, $32(2), 273-294$.

Macias, H., \& Farfan-Lievano, A. (2017). Integrated reporting as a strategy for firm growth: Multiple case study in Colombia. Meditari Accounting Research, 25(4), 605-628.

Madi, H. K., Ishak, Z., \& Manaf, N. A. A. (2014). The impact of audit committee characteristics on corporate voluntary disclosure. Procedia - Social and Behavioral Sciences, 164(1), 486-492.

Magnaghi, E., \& Aprile, R. (2014). Integrated reporting: A theoretical perspective on this critical issue. Journal of Business and Economics, 5(8), 1320-1337.

Marcon, C., \& Mancin, M. (2016). Empirical evidence on current integrated reporting practices. In Mio C. (Eds.), Integrated reporting: A new accounting disclosure (pp. 59-80). London: Palgrave Macmillan.

Marston, C., \& Polei, A. (2004). Corporate reporting on the Internet by German companies. International Journal of Accounting Information Systems, 5(3), 285-311.Available at: https://doi.org/10.1016/j.accinf.2004.02.009.

Matemane, R., \& Wentzel, R. (2019). Integrated reporting and financial performance of South African listed banks. Banks and Bank Systems, 14(2), 128-139.

Meek, G. K., Roberts, C. B., \& Gray, S. J. (1995). Factors influencing voluntary annual report disclosures by US, UK and continental European multinational corporations. Journal of International Business Studies, 26(3), 555-572.Available at: https://doi.org/10.1057/palgrave.jibs.8490186.

Nakib, M., \& Dey, P. K. (2018). The journey towards integrated reporting in Bangladesh. Asian Economic and Financial Revierw, 8(7), 894-913.Available at: https://doi.org/10.18488/journal.aefr.2018.87.894.913.

Oliveira, L., Rodrigues, L., \& Craig, R. (2010). Intellectual capital reporting in sustainability reports. Journal of Intellectual Capital, $11(4), 575-594$. Available at: https://doi.org/10.1108/14691931011085696.

Peršić, M., \& Halmi, L. (2017). Non-financial information and integrating reporting in the hospitality industry: Case study of Croatia. Copernican Journal of Finance \& Accounting, 6(3), 95-109.Available at: https://doi.org/10.12775/cjfa.2017.019.

Pistoni, A., Songini, L., \& Bavagnoli, F. (2018). Integrated reporting quality: An empirical analysis. Corporate Social Responsibility and Environmental Management, 25(4), 489-507.Available at: https://doi.org/10.1002/csr.1474. 
Porta, R. L., Lopez-De-Silanes, F., Shleifer, A., \& Vishny, R. W. (1998). Law and finance. Journal of Political Economy, 106(6), 1113-1155.

Prado-Lorenzo, J. M., Garcia-Sanchez, I. M., \& Blazequez-Zaballos, A. (2012). The impact of the cultural system on institutional transparency. The Company's European Management and Economics Magazine, 22(3), 143-154.

PricewaterhouseCoopers. (2014). Corporate performance: What do investors want to know? Retrieved from https://www.pwc.com/gx/en/audit-services/corporate-reporting/publications/investor-view/assets/pwc-investorssurvey-powerful-stories-through-integrated-reporting.pdf.

Roe, M. (1994). Strong managers, weak owners: The political roots of American corporate finance. NJ/Princeton: Princeton University Press.

Roe, M. J. (1991). A political theory of American corporate finance. Columbia Law Revierw, 91(1), 10-67.Available at: https://doi.org/10.2307/1122856.

Rowbottom, N., \& Locke, J. (2013). The emergence of integrated reporting. Paper presented at the Seventh Asia Pacific Interdisciplinary Research in Accounting Conference, Kobe.

Rupley, K. H., Brown, D., \& Marshall, S. (2017). Evolution of corporate reporting: From stand-alone corporate social responsibility reporting to integrated reporting. Research in Accounting Regulation, 29(2), 172-176.Available at: https://doi.org/10.1016/j.racreg.2017.09.010.

Setia, N., Abhayawansa, S., Joshi, M., \& Huynh, A. (2015). Integrated reporting in South Africa: Some initial evidence. Sustainability Accounting, Management and Policy Journal, 6(3), 397-424.Available at: https://doi.org/10.1 108/sampj-032014-0018.

Shabeeb, M., \& Ahmed, A. (2016). Toward integrated reporting: An explanatory analysis of reporting practices in Saudi Arabia. Accounting Thought Journal, 21(1), 53-121.

Simnett, R., Vanstraelen, A., \& Chua, W. F. (2009). Assurance on sustainability reports: An international comparison. The Accounting Review, 84(3), 937-967.Available at: https://doi.org/10.2308/accr.2009.84.3.937.

Smith, V. D. L. J., Adhikari, A., \& Tondkar, R. H. (2005). Exploring differences in social disclosures internationally: A stakeholder perspective. Journal of Accounting and Public Policy, 24(2), 123-151.Available at: https://doi.org/10.1016/j.jaccpubpol.2004.12.007.

Solomon, J., \& Maroun, W. (2012). Integrated reporting: The influence of King III on social, ethical and environmental reporting. The Association of Chartered Certified Accountants. Retrieved from https://www.accaglobal.com/content/dam/acca/global/PDF-technical/integrated-reporting/tech-tp-iirsa.pdf.

South African Institute of Chartered Accountants. (2010). An integrated report is a new requirement for listed companies (pp. 21-28). Johannesburg, South Africa: SAICA.

Toit, E. D., Van Zyl, R., \& Schütte, G. (2017). Integrated reporting by South African companies: A case study. Meditari Accountancy Research, 25(4), 654-674.Available at: https://doi.org/10.1108/medar-03-2016-0052.

Uyar, A., Kilic, M., \& Bayyurt, N. (2013). Association between firm characteristics and corporate voluntary disclosure: Evidence from Turkish listed companies. Intangible Capital, 9(4), 1080-1112.Available at: https://doi.org/10.3926/ic.439.

Vitolla, F., \& Raimo, N. (2018). Adoption of integrated reporting: Reasons and benefits-a case study analysis. International Journal of Business and Management, 13(12), 244-250.Available at: https://doi.org/10.5539/ijbm.v13n12p244.

Yen, A. (2004). Effects on investor judgements from expanded disclosures of non-financial intangibles information. Unpublished PhD Thesis, The University of Texas at Austin, Austin, United States. 


\section{APPENDIX}

Table-A1. List of disclosure items.

\begin{tabular}{|c|c|}
\hline Content categories & Disclosure items \\
\hline \multirow{6}{*}{ (A) Organizational overview and outlook } & 1. Integration of sustainability within corporate mission/vision \\
\hline & 2. Stating corporate ethics and values \\
\hline & 3. Showing the organization's principal activities and markets \\
\hline & 4. Providing the implications for future financial performance \\
\hline & $\begin{array}{l}\text { 5. Describing the reporting boundary (i.e., subsidiaries and associates, as } \\
\text { well as the related parties, included) }\end{array}$ \\
\hline & $\begin{array}{l}\text { 6. Describing the frameworks used to quantify material aspects (e.g., The } \\
\text { accounting standards, corporate social responsibility (CSR) framework) }\end{array}$ \\
\hline \multirow{6}{*}{ (B) Governance } & 7. Clear leadership structure \\
\hline & $\begin{array}{l}\text { 8. Processes/ actions taken to influence and monitor the strategic } \\
\text { direction of the organization }\end{array}$ \\
\hline & $\begin{array}{l}\text { 9. How the organization's leadership engage with key stakeholders to } \\
\text { create value }\end{array}$ \\
\hline & 10. Governance practices that exceed legal requirements \\
\hline & 11. How the organization's leadership promote and enable innovation \\
\hline & 12. Linking remuneration and incentives with value creation \\
\hline \multirow{7}{*}{ (C) Business model } & 13. Identifying material matters affecting value creation \\
\hline & 14. Identification of key stakeholders \\
\hline & 15. Product and service innovations \\
\hline & 16. Improvement of processes \\
\hline & 17. Training employees on sustainability aspects \\
\hline & 18. Managing relationships with suppliers \\
\hline & 19. Identification of by-products and waste \\
\hline \multirow{12}{*}{ (D) Risk and opportunities } & 20. Identifying material internal risks \\
\hline & 21. Identifying material internal opportunities \\
\hline & 22. Identifying material external economic risks \\
\hline & 23. Identifying material external economic opportunities \\
\hline & 24. Identifying material external environmental risks \\
\hline & 25. Identifying material external environmental opportunities \\
\hline & 26. Identifying material external social risks \\
\hline & 27. Identifying material external social opportunities \\
\hline & 28. Identifying material external legal risks \\
\hline & 29. Identifying material external political risks \\
\hline & 30. Assessment of the potential risks coming to fruition \\
\hline & 31. Assessment of the potential opportunities coming to fruition \\
\hline \multirow{7}{*}{ (E) Strategy and resource allocation } & 32. Identifying short-, medium-, and long-term strategic objectives \\
\hline & 33. Resource allocation for implementing the strategy \\
\hline & 34. Identifying the means to assess the implementation of the strategy \\
\hline & 35. How stakeholders' insights form part of the organization's strategy \\
\hline & $\begin{array}{l}\text { 36. Describing the social and environmental aspects included in the } \\
\text { organization's strategy }\end{array}$ \\
\hline & $\begin{array}{l}\text { 37. Identifying the changes required to the business model for } \\
\text { implementation of the strategy }\end{array}$ \\
\hline & 38. How the strategies respond to external risks and opportunities \\
\hline \multirow{7}{*}{ (F) Performance } & 39. Quantitative indicators for the organization's targets \\
\hline & 40. Quantitative indicators for risks and opportunities \\
\hline & $\begin{array}{l}\text { 41. Explaining the organization's capacity to respond to the stakeholders' } \\
\text { needs }\end{array}$ \\
\hline & 42. Showing the link between past and current performance \\
\hline & 43. Showing the link between current performance and future outlook \\
\hline & 44. KPIs linking financial and non-financial measures \\
\hline & 45. Identifying constraints on performance due to regulatory compliance \\
\hline
\end{tabular}

Source: International Integrated Reporting Council, 2013. 